\title{
Integration of Solar Panels as the Shading Devices to Lower the Indoor Air Temperatures
}

\author{
Jefrey I. Kindangen*, Veronica A. Kumurur, Octavianus H. Rogi \\ Department of Architecture, Faculty of Engineering, Sam Ratulangi University, Manado 95115, Indonesia
}

Received November 21, 2020; Revised December 22, 2020; Accepted January 28, 2021

\section{Cite This Paper in the following Citation Styles}

(a): [1] Jefrey I. Kindangen, Veronica A. Kumurur, Octavianus H. Rogi, "Integration of Solar Panels as the Shading Devices to Lower the Indoor Air Temperatures," Civil Engineering and Architecture, Vol. 9, No. 1, pp. 115-123, 2021. DOI: 10.13189/cea.2021.090109.

(b): Jefrey I. Kindangen, Veronica A. Kumurur, Octavianus H. Rogi (2021). Integration of Solar Panels as the Shading Devices to Lower the Indoor Air Temperatures. Civil Engineering and Architecture, 9(1), 115-123. DOI: 10.13189/cea.2021.090109.

Copyright $\odot 2021$ by authors, all rights reserved. Authors agree that this article remains permanently open access under the terms of the Creative Commons Attribution License 4.0 International License

\begin{abstract}
This study tries to verify how the integration of solar panels as a shading device can reduce indoor air temperature. Two stages of the experiment have been conducted, the first experiment compared the shadowing performance of the solar panels placed parallel in front of the window, while the second experiment compared the shadowing performance of the solar panels placed 45 degrees on the top edge of the window with the panels aligned in front of the window. Two models of similar buildings have been built; to see how much influence the location of solar panels as a shading device, the surface temperature of the glass and indoor air temperature were measured using temperature and humidity data loggers. The measurement results of the first experiment showed that compared to a model without solar panels, especially from 7 a.m. to 5 p.m., significantly decreased by an average of $2.5^{\circ} \mathrm{C}$ and $0.6^{\circ} \mathrm{C}$ consecutively to the glass surface temperatures and the indoor air temperatures. In the second experiment, the comparison of shadowing performance between solar panels placed parallel in front of the window with panels placed tilted 45 degrees indicates that especially for windows on the East side the use of solar panels placed parallel in front of the window is more potential. This result also has the potential to become a renewable energy source, but further research is still needed, especially regarding solar panel electricity production capacity.
\end{abstract}

Keywords Solar Panel, Shading Devices, Indoor Air Temperature, Thermal Comfort

\section{Introduction}

Hot air and high humidity are the main problems faced by buildings in humid tropical climates. This condition is the main cause of discomfort in the occupancy space in the building. Increasing the average air temperature due to climate change must be anticipated more seriously, which causes excessive heating in the space in a building. The greater the increase in air temperature in the room the greater the energy needed for cooling. This problem is exacerbated by the increasingly limited sources of non-renewable energy from fossils and the price is increasingly expensive. Therefore, using this energy efficiently and economically becomes a central issue of the world today, and seeks to find other energy alternatives and efforts to economize energy; including of course in the building construction sector [1].

About $40 \%$ of energy is consumed to be used as indoor air cooling in office buildings and housing. Especially when a building is designed regardless of the site and environmental conditions of the surrounding location, using inappropriate building materials, not using shading to avoid direct sunlight, all this will increase energy consumption. Understandably, the average building in a humid tropical climate is faced with the problem of how to achieve and maintain comfortable indoor conditions where air temperature and humidity can be controlled.

Passive cooling is one strategy for energy-efficient buildings that are needed for cooling buildings in humid tropical climates. Several passive cooling strategies can be applied in our climate in Indonesia, the most popular and 
widely known are comfort ventilation. This technique will be better applied with shading techniques in areas of walls and windows that are exposed to direct sunlight. The use of shading functions as a "barrier" against direct heating of the walls or windows of the building. The application of shading devices can be an enhancer of the aesthetic facade of the building.

Indonesia's astronomical location located on the equator affects the magnitude and intensity of solar radiation in the building as a whole, especially in openings or transparent fields such as windows. Thus, the application of shading devices on windows or other wall surfaces is interesting to study, especially the integration of solar panels as shading devices and their effect on decreasing internal room temperature; also a system for producing renewable energy is an important object. This is because the benefits of integrating solar panels into shading device systems and renewable energy sources that can be used for housing needs will provide many benefits. Solar panels can produce electricity that can be used for household needs. The solar panel will function as an element of the shading device that protects and overshadows the window from direct solar radiation so that it can be called direct sunlight protection on windows or other openings. The position and dimensions of panel construction require in-depth research, especially the effect on decreasing indoor temperature.

Research on solar heating control and shading devices is very important when architects and designers want to build homes that are both energy efficient and thermally comfortable. There are several studies of shading devices such as those by Ahmed et al. [2] who concluded that the use of permanent shading devices can improve thermal performance in office space. Whereas Barbara Matusiak [3] has conducted a study of permanent shading devices and proposed a design method for permanent exterior shading devices, Dubois [4] explained the results of her research that a method determines imaging devices. These studies are carried out in temperate climates and certainly different if applied in a humid tropical climate. Whereas Chia-Peng [5] reported that imaging devices in architectural design can control the level of lighting with natural lighting, while Carmody [6] researched with commercial building objects.

Research by Lee et al. [7] and Yao et al. [8] concluded that shading device systems, especially from the economic aspects of buildings and their operational systems, can save energy significantly. The European Commission [9] in the Thermie program published a shading system for climate in Europe; thus, references that are suitable for the Southeast Asian climate are still very limited and even similar studies have not been published to date. Research on materials, typology, and orientation of shading devices have been carried out by Gutierez [10] who concluded that experimental studies conducted were very useful for building shading design databases. External shade devices to maximize visual appearance and performance in terms of natural lighting have been carried out by Kim et al. [11]. Similarly, the results of research from Hien et al. [12] and Corrado et al. [13] reported an analysis of several important influences of shading tools outside of natural lighting and ventilation. Rosencrantz [14] in his doctoral thesis study reported that evaluating through measuring and simulating the performance of windows and shading devices contributed significantly to energy efficiency.

Research on shading devices was carried out by researcher Lu et al. [15] which used a simple light sensor to obtain a smart shading device system. Pablo la Roche [16] proposed a smart passive system to achieve carbon-neutral buildings or zero-emission buildings. He also researched in 2005 on the effects of a combination of smart shading devices and ventilation for thermal comfort. One of the researchers who produced many publications in intelligent control was Selkowitz [17-19] especially in the automation of shading devices and smart glass for natural lighting control. Buhagiar et al. [20] strengthened the results of Selkowitz's research primarily for application to the Mediterranean climate.

Gaur et al. [21] and MacKay [22] reported their research on the performance of solar panels and informed that in locations with full sunlight, the benefits of solar panels are $10 \mathrm{~W} / \mathrm{m}^{2}$; where [21] more broadly examined several different solar cells. The use of solar panels in Indonesia has great potential because it is more efficient and more affordable by taking advantage of economic and environmental benefits, as studied by [23] who used solar panels to power water pumps for daily needs.

So far and rarely have there been references to the thermal performance of shading devices using solar panels applied to windows in general as described above. In connection with these limitations, the initiator formulated the main problem of this study to examine the effect of shading from integrated solar panels on the windows of a house building.

\section{Materials and Methods}

This study was conducted in Manado in the North Sulawesi province of Indonesia, which is located at $1.4583^{\circ}$ North Latitude and $124.8260^{\circ}$ East Longitude, as shown in Fig. 1. 


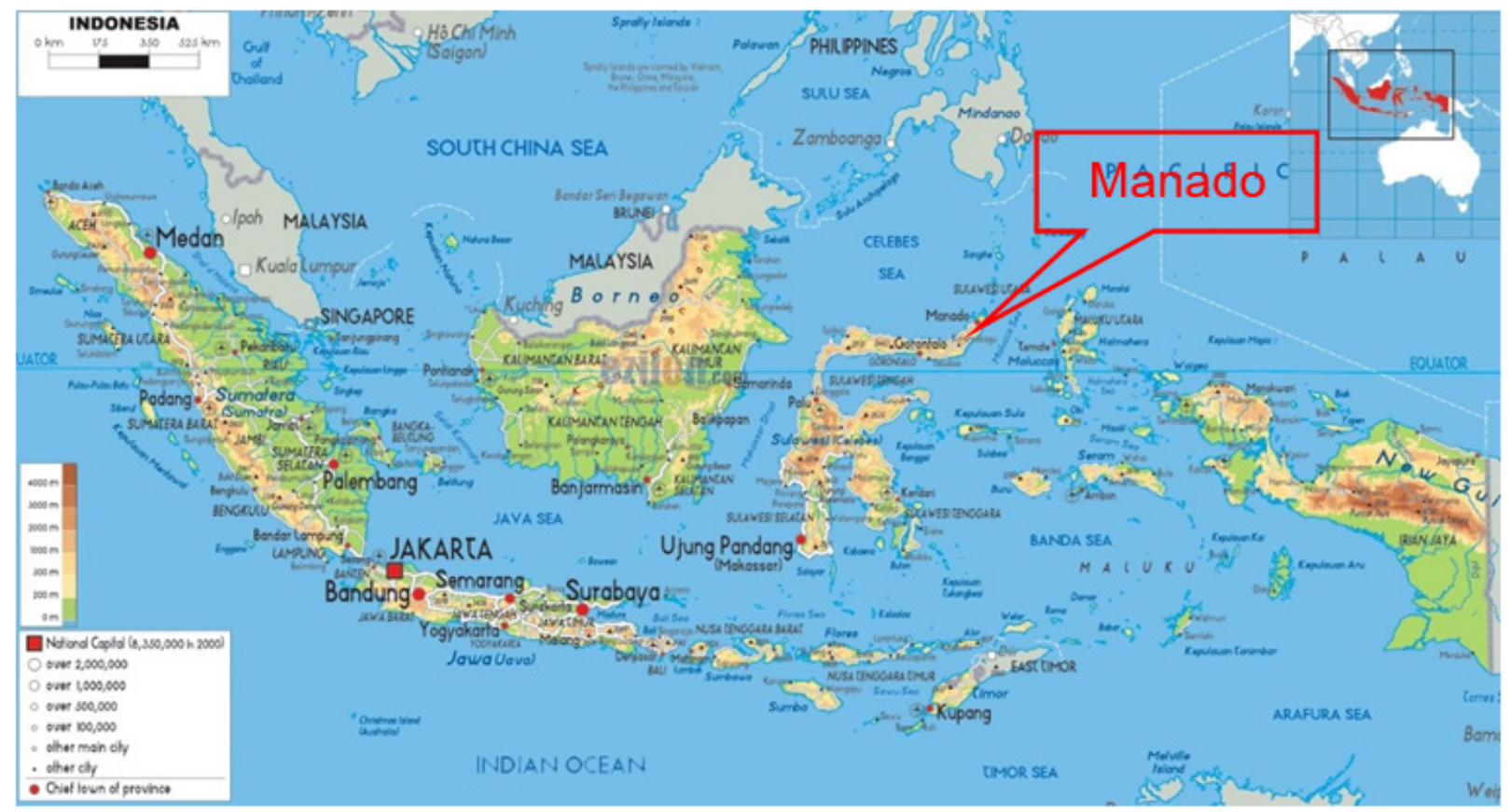

Figure 1. Indonesia's map

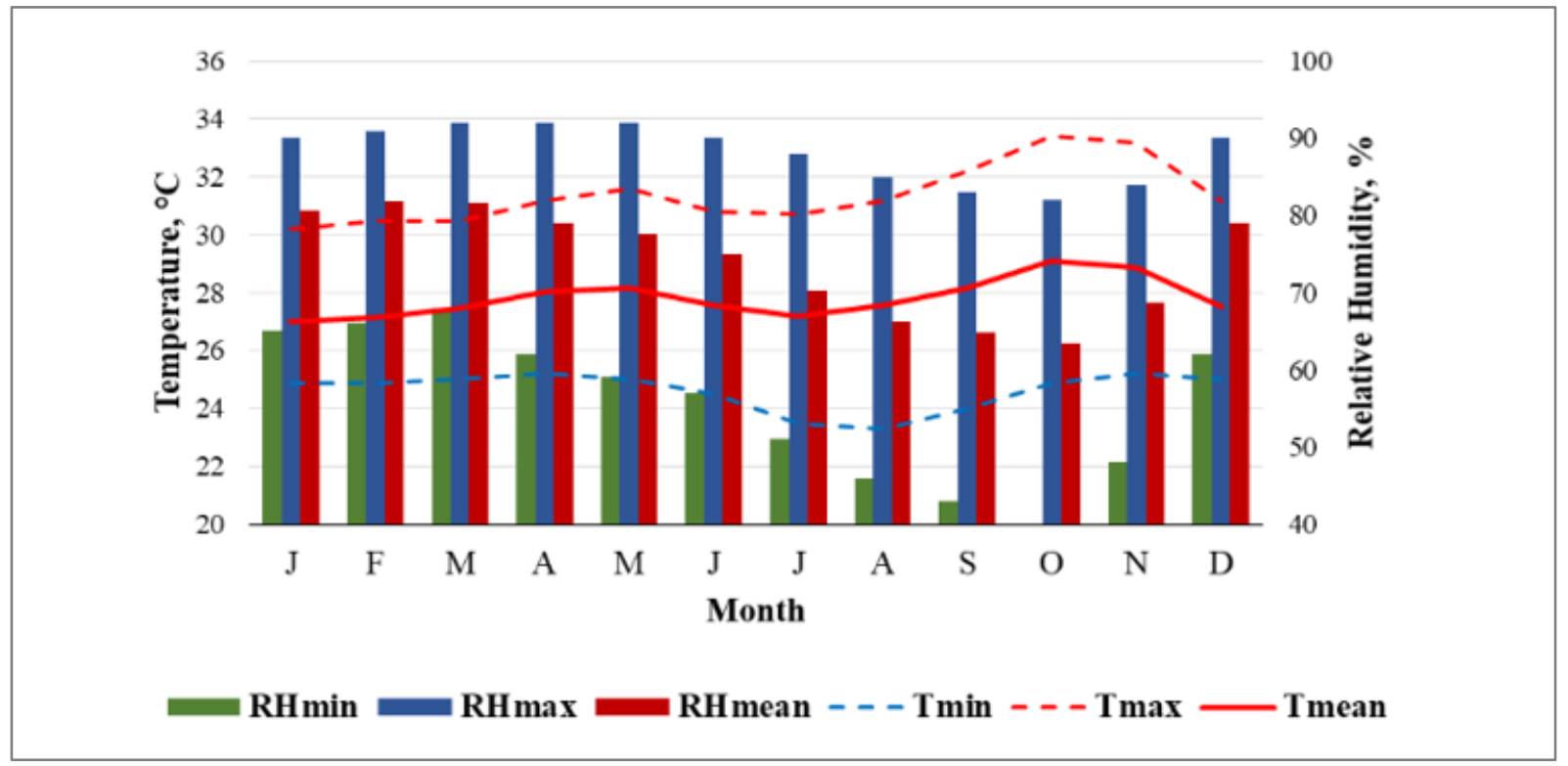

Figure 2. The climatic condition of Manado

The city of Manado is influenced by a humid tropical climate with an average temperature of $29.10^{\circ} \mathrm{C}$ in October and the coldest month is January with an average temperature of $26.90^{\circ} \mathrm{C}$. In general, the temperature difference between the warmest and coldest months is not very large. November-March is the rainy season period with the largest average rainfall occurring in January (465 $\mathrm{mm}$ ). Daily and monthly temperature amplitude is small. Average high relative humidity ranges from $64 \%$ in October and $81 \%$ in January and March, as shown in Fig. 2.

Two similar test cells were constructed with a length of
$1.00 \mathrm{~m}$, a width of $1.00 \mathrm{~m}$, and a height of $1.85 \mathrm{~m}$. The walls of the two test cells were made of the unpainted wood multiplex. The roof is made of corrugated galvanized zinc sheet with a surface area of $2.60 \mathrm{~m}^{2}$. Each test cell has two windows measuring $25 \times 50 \mathrm{~cm}$ with a window sill $70 \mathrm{~cm}$ above ground level, located on the right and left (East and West sides). One of the windows on the Eastside was fitted with $2 \mathrm{~mm}$ glass panes while the window on the Westside had no panes and was left open.

For this purpose, two stages of experimentation have been carried out. In the first experiment, a comparison 
was made between a model that has solar panels and a model without solar panels. One of the windows of both models is fitted with glass resembling a transparent glass window.

In the East window, solar panels are installed as shading devices with a distance of $10 \mathrm{~cm}$ parallel to the glass field. The test cell has an attic that has ventilation holes for $20 \%$ of the attic area. The two test cells were placed in a courtyard that allowed as much direct sunlight as possible in the morning, as illustrated in Fig. 3.

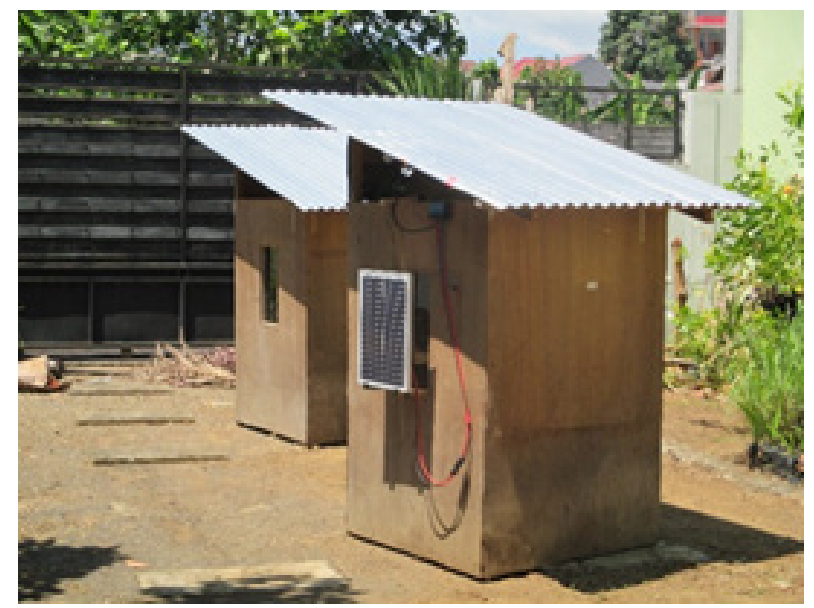

Figure 3. In the first experiment, two models have been built which one installed solar panels parallel to the window and the other not

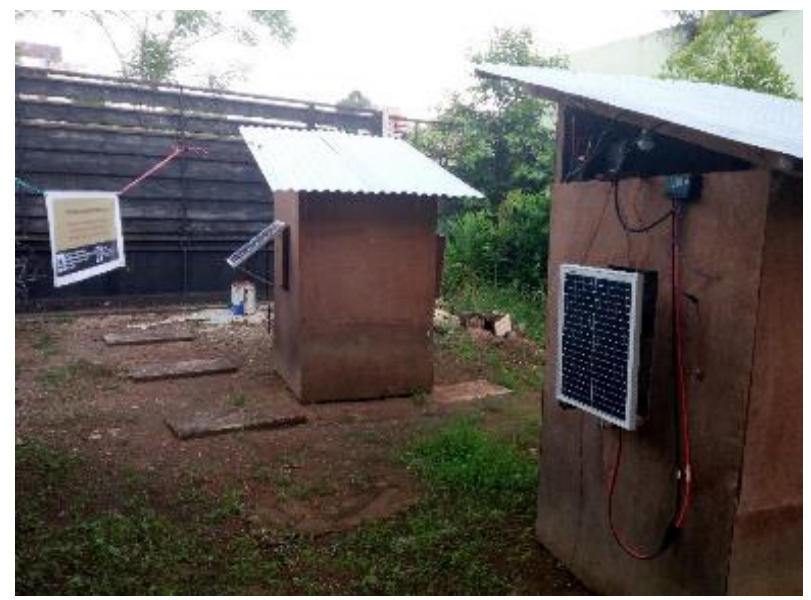

Figure 4. In the second experiment, two models were built, one fitted with a window-aligned solar panel and the other fitted with a solar panel with a $45^{\circ}$ slope

In the second experiment, a comparison of the position of solar panels on the windows was placed on both models. One model is fitted with parallel solar panels while the other model is fitted with solar panels on top of the window with a slope of 45 degrees, as shown in Fig. 4.
A polycrystalline $20 \mathrm{WP}$ solar panel was used, it weighs $2.3 \mathrm{~kg}$, has a dimension of $485 \times 360 \times 25 \mathrm{~mm}$, has a production tolerance of $0-3 \%$, a maximum power current of $1.08 \mathrm{~A}$, and a maximum power voltage of 18.5 $\mathrm{V}$, and loads mechanically tested 2,400 Psi. Measurements were made to examine the effect of solar panel placement as a shading device using data loggers $\mathrm{RC} 4-\mathrm{HC}$ which measures the air temperature and relative humidity of the room and glass surface of the model that is not fitted with solar panels or models with solar panels. For each model, a thermohygrometer data logger was placed in the test cell to record the temperature and relative humidity of the indoor air, and another data logger was placed and mounted on the glass surface to measure and record the surface temperature of the glass windows. Measurements were taken for 2 weeks each in August and October during sunny weather. Because the amplitude of daily and monthly temperatures for a year is small; it can be assumed that the measurements at that time are acceptable and representative.

The use of flexible solar panels will provide flexibility in designing various forms of shading devices. This will be very favored by architects and designs in integrating aesthetic shading devices as well as useful as an alternative energy source, as shown in Fig. 5.

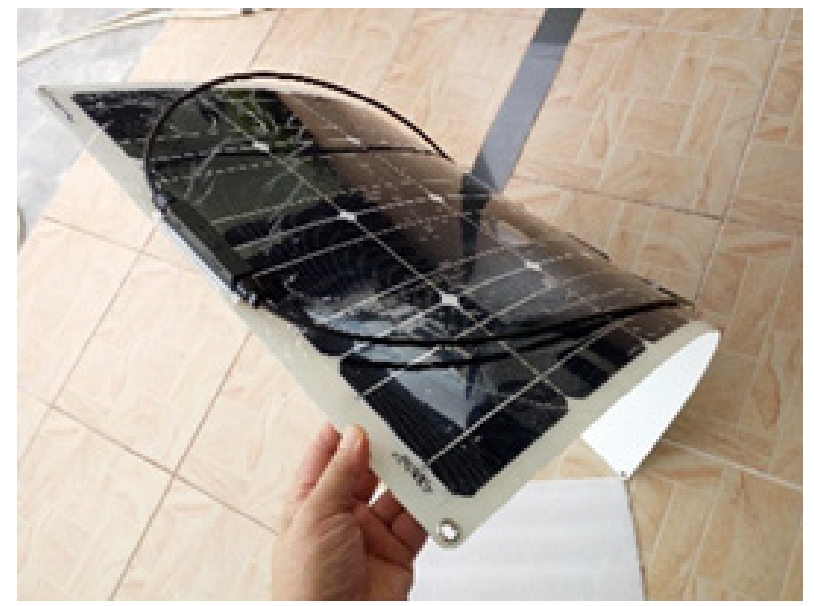

Figure 5. The flexible solar panels are easier to apply as any form of shading devices

\section{Results and Discussion}

Measurements carried out sequentially for two weeks showed that the indoor air temperature in the glass window was protected by solar panels, from 7 a.m. to 5 p.m., always lower than the indoor air temperature on models without solar panels, as shown in Fig. 6. 
40

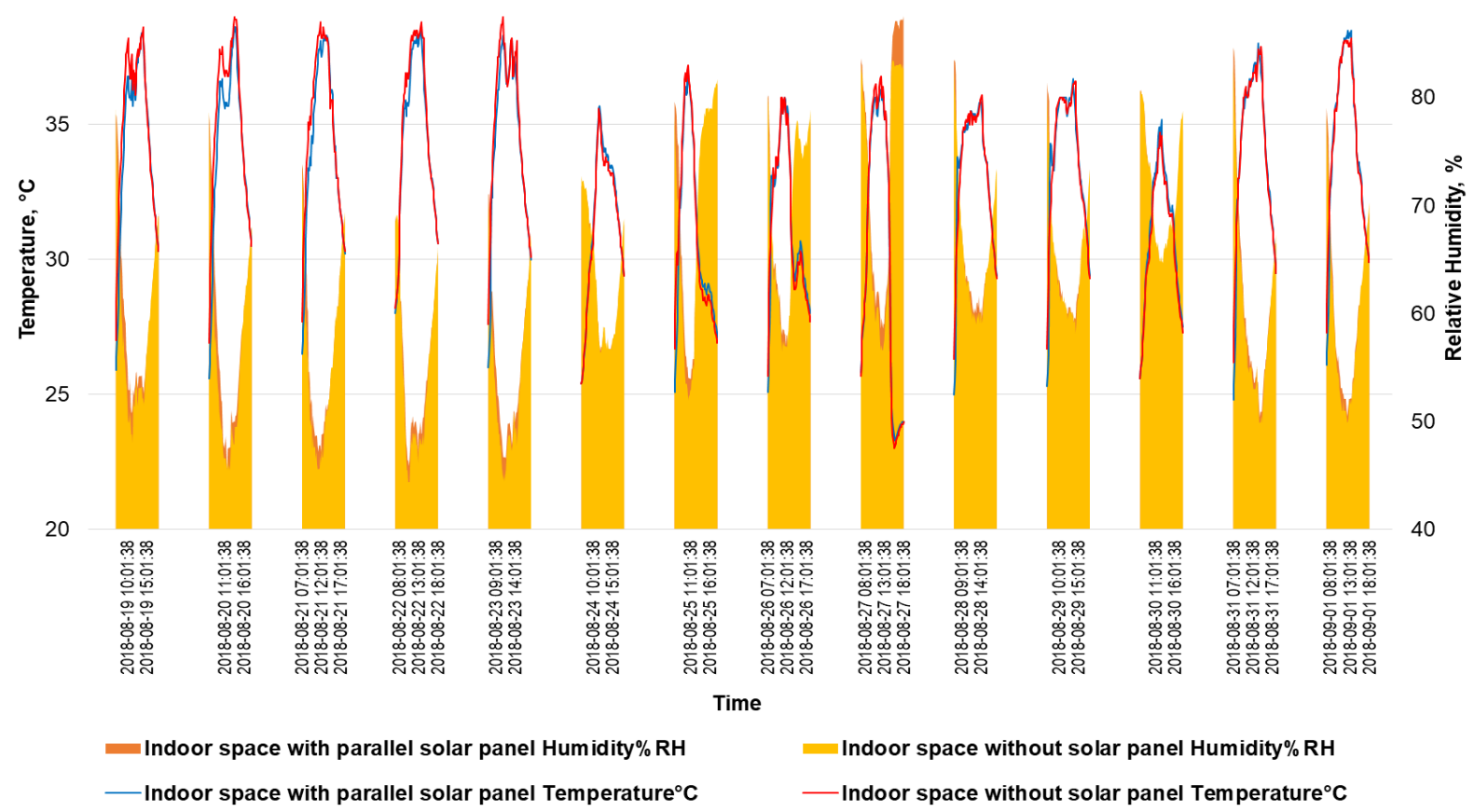

Figure 6. Comparison of the indoor air temperatures and its relative humidity between a model with solar panels and without solar panel for two weeks

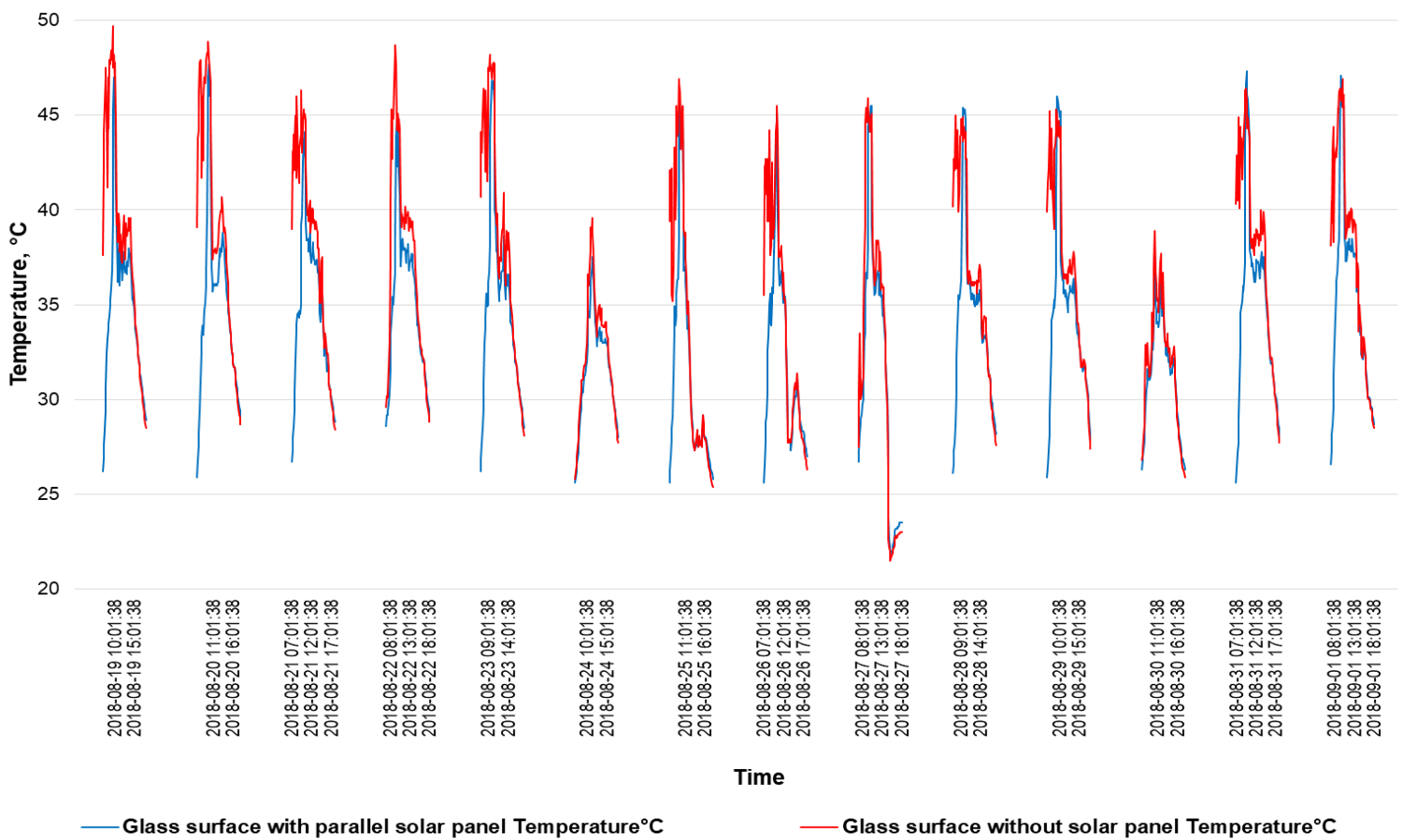

Figure 7. Comparison of glass surface temperatures between a model with a solar panel and without solar panel for two weeks

Indoor air temperature is very dependent on many parameters such as weather conditions at the same time; so that the curve of indoor air temperature always fluctuates according to weather conditions. While relative humidity fluctuates according to air temperature. The lowest room air temperature is $24.8^{\circ} \mathrm{C}$, and the highest is $38.1^{\circ} \mathrm{C}$; with the relative humidity respectively of $84.8 \%$ and $47.8 \%$.
This is also the case with Figure 7, which shows the comparison of the glass surface temperature between the window model covered by the solar panel and not. In general, the surface temperature of the window glass covered by the panel is always lower than the temperature of the glass surface that is not covered. During the measurement time, the lowest temperature of the glass surface is $21.6^{\circ} \mathrm{C}$, and the highest is $48.7^{\circ} \mathrm{C}$. 
The average difference in indoor air temperature and the glass surface is $0.6^{\circ} \mathrm{C}$ and $2.5^{\circ} \mathrm{C}$ respectively, where indoor air temperature from a window with a solar panel is always lower than without a solar panel. The biggest difference in indoor air temperature between the two models occurred at 7.40 a.m. at $3.1^{\circ} \mathrm{C}$ and gradually declined until 11 a.m., indicating that the position of the solar panels placed in the east window will always be effective to withstand heat from direct sunlight when the morning. At the same time, this also applies to the comparison of the surface temperature of the glass between the models on which the windows are fitted with solar panels and those that don't; the temperature difference is around $17.6^{\circ} \mathrm{C}$ at the same time as mentioned above, as shown in Fig. 8 and 9.

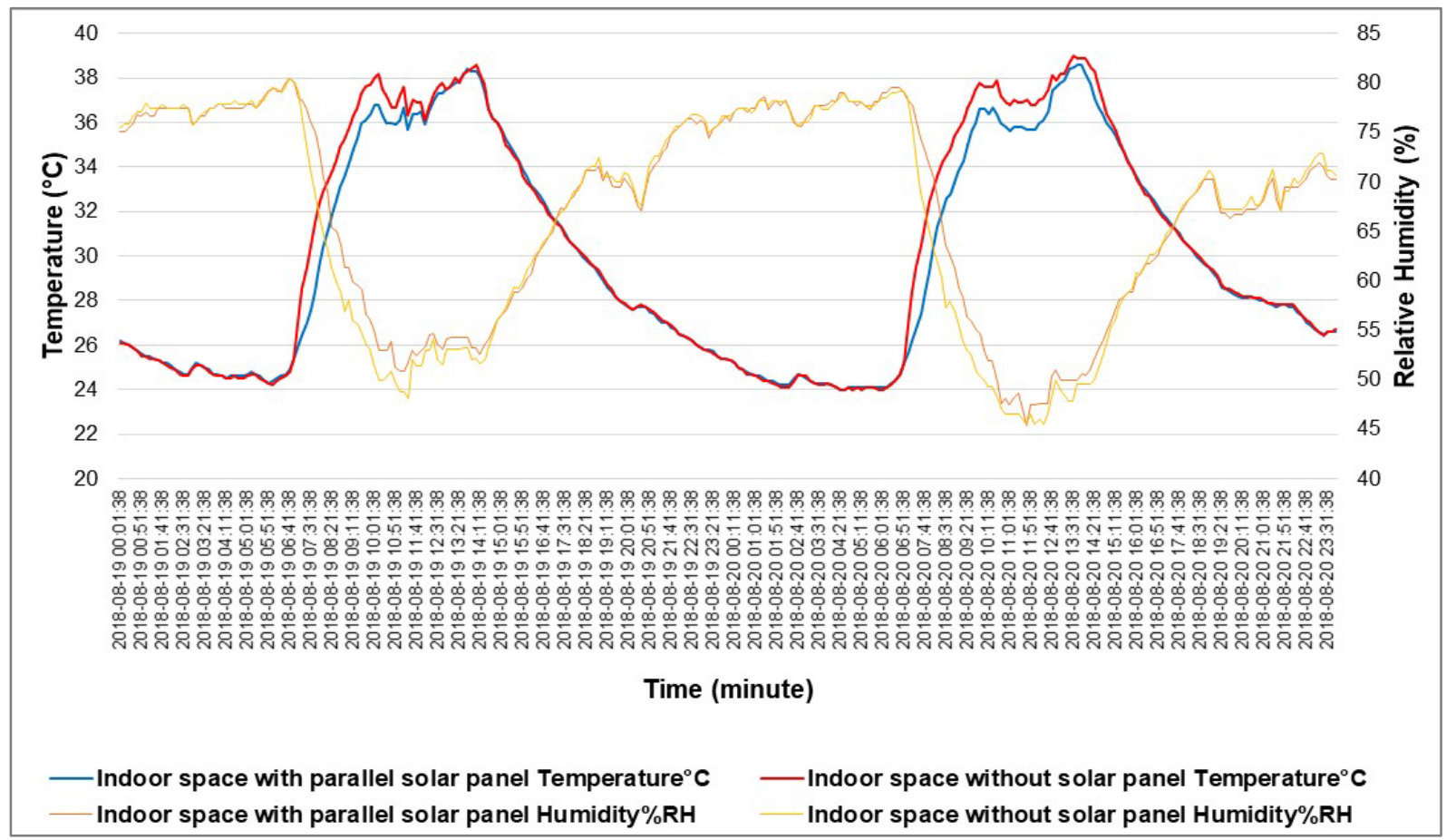

Figure 8. Comparison of indoor air temperature and humidity between a model with a solar panel and a model without solar panel

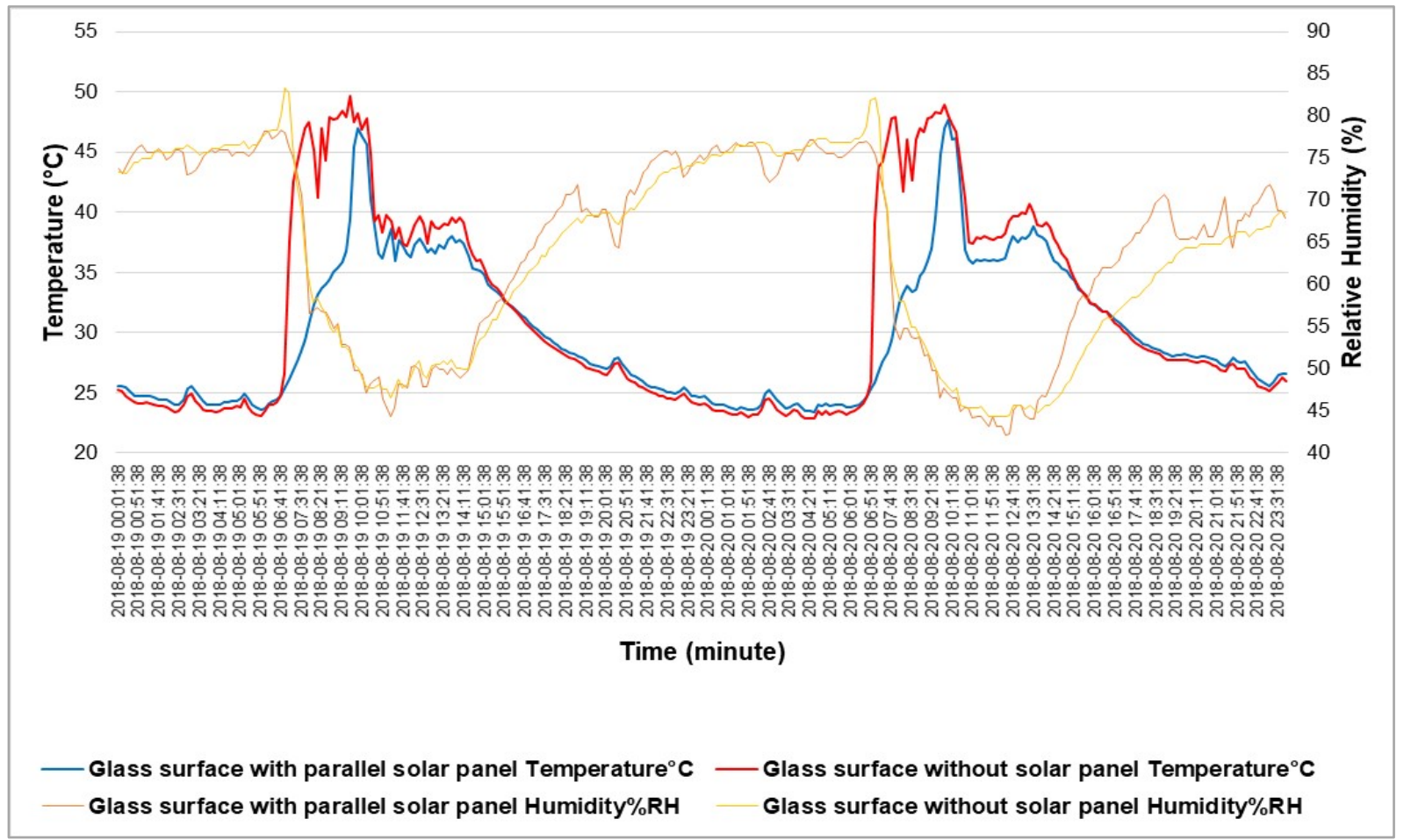

Figure 9. Comparison of glass surface temperature and humidity between the model with a solar panel and model without solar panel 
The glass surface temperatures are very different, they gradually decrease until 11 p.m. At night the glass surface temperature difference is not too much even the same. Overall it shows that the use of solar panels as an effective shading device to reduce indoor air temperature as well as an alternative energy source. Battery charging is effective at these hours, from 7 to 11 a.m.

The second experiment where the comparison of solar panel performance with parallel position and tilt position of 45 degrees. It is observed that the surface temperature of the glass from the model with solar panels that are placed parallel windows is always hotter in the morning while in the afternoon until the afternoon it is always colder. The position of the window facing east has a significant influence on the temperature curve of the glass surface. Thus this will greatly affect the indoor temperature where the same pattern of models with parallel solar panels will be hotter in the morning while in the afternoon until the afternoon is colder. This can be seen more clearly by taking one day only as shown in the chart below.

Solar panels placed tilted in front of glass windows give the effect of lower temperatures or less than the influence of parallel panels, while parallel panels cause the surface temperature of the glass to rise larger until 10 a.m.

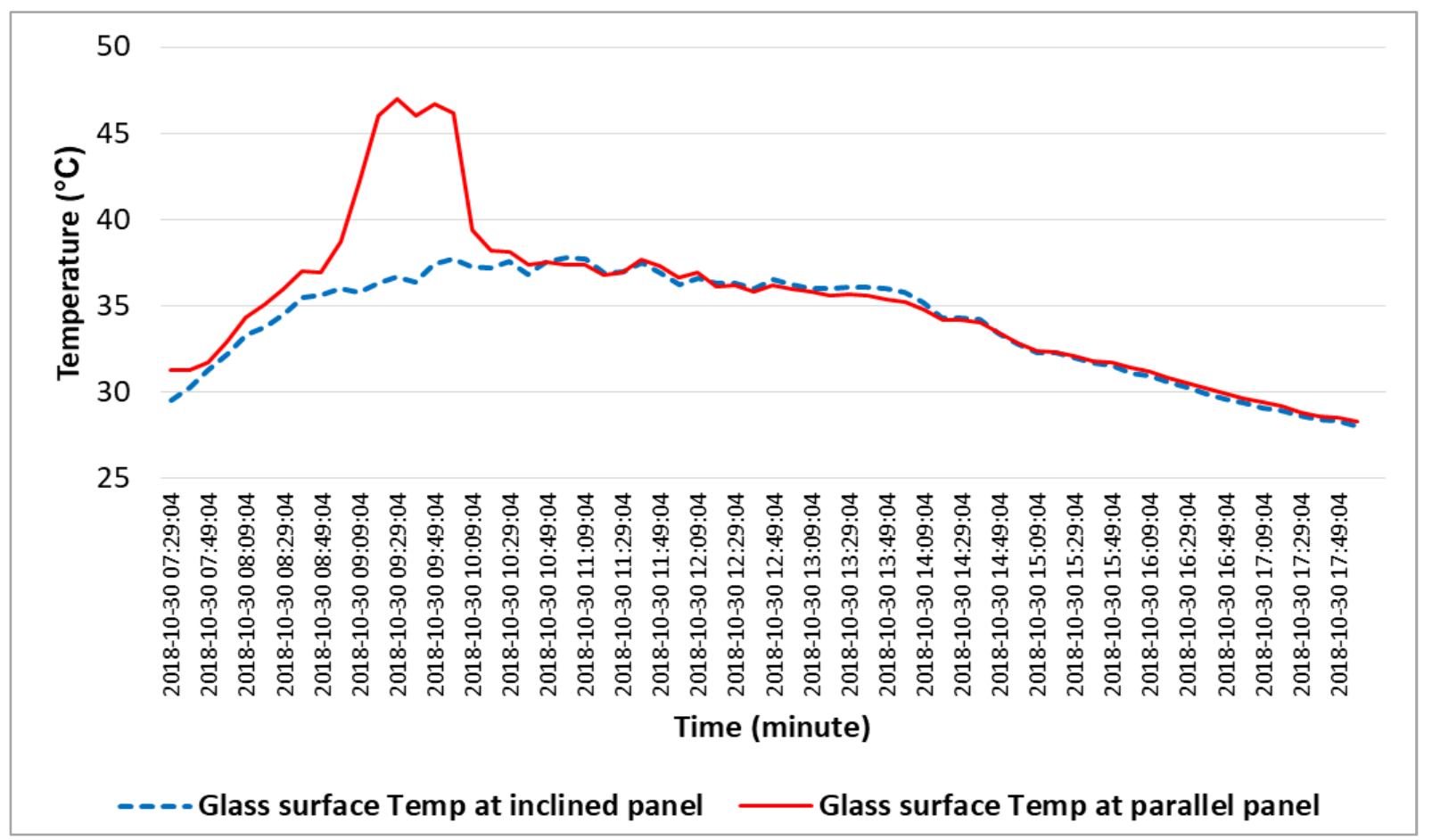

Figure 10. Comparison of the temperature of the glass surface of the model with solar panels placed parallel and tilted on the front of the window on the Eastside

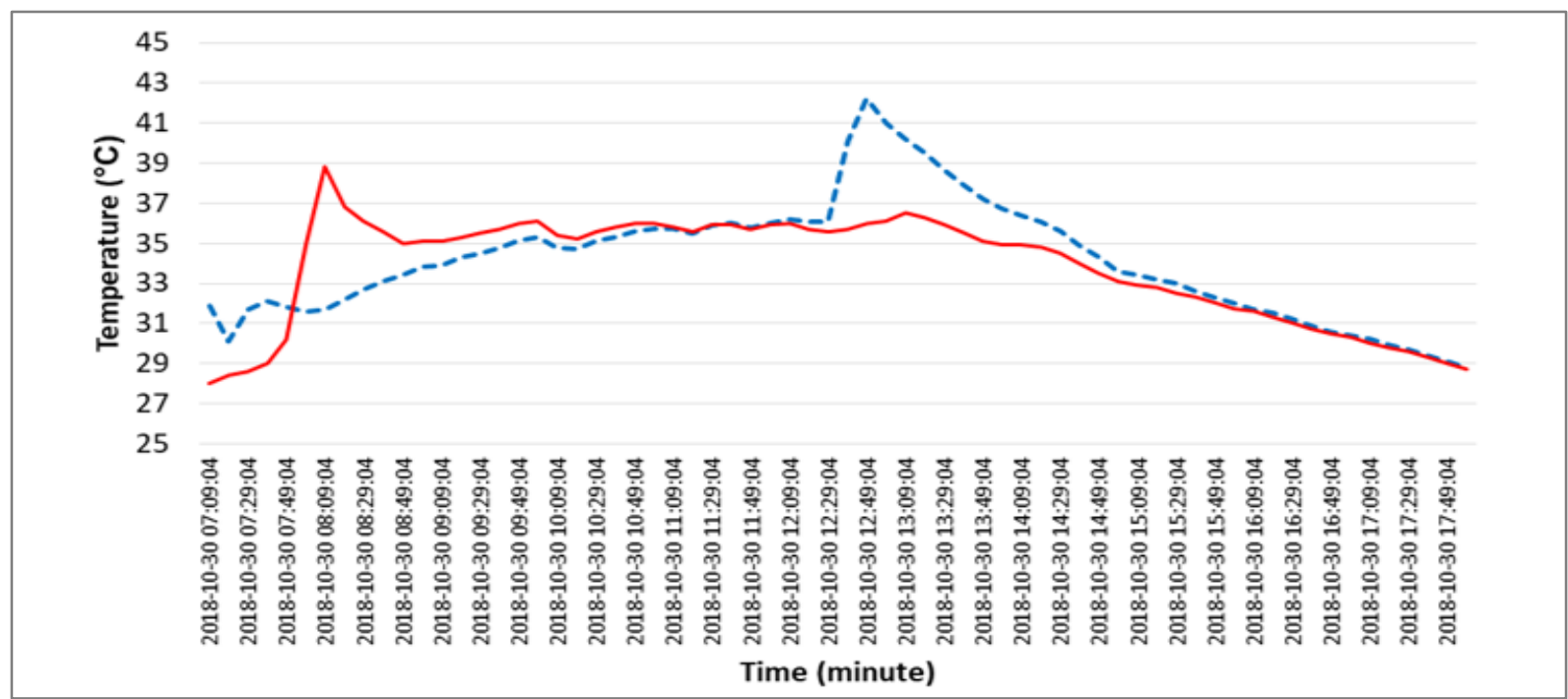

Figure 11. Comparison of indoor temperature due to laying of parallel and tilted solar panels on windows on the Eastside 
The indoor air temperature on the model with solar panels placed parallel in front of the windows on the Eastside will have a better influence compared to the model that use tilted solar panels. This can be seen in figure 11 where the air temperature of the indoor increases only in the morning i.e. at 7-10 in the remaining hours lower or equal to the indoor air temperatures of the model whose solar panels are placed tilted on the window face. Thus we can conclude that the model of laying solar panels on windows on the Eastside preferably in a parallel position closes the surface of the window hole.

\section{Conclusions}

The use of solar panels placed in front of glass windows as shading devices has shown their usefulness, where in general, room air temperature is always lower than models that do not use solar panels. Especially during the day, the advantage of using double layers is that room temperatures are lower at an average of $0.6{ }^{\circ} \mathrm{C}$. This gives confidence that this system can be applied to buildings in North Sulawesi, even Indonesia.

Lowering the temperature of the glass surface, in turn, allows a decrease in the indoor air temperature during the day. The glass surface temperature of the model with solar panels on the windows is always lower by an average of $2.5^{\circ} \mathrm{C}$ than on a model without it. The comparison between the model and the parallel solar panel window with the panel that tilts 45 degrees gives the conclusion that for the position of the window located on the East side put the solar panel parallel to the window is better than the panel with the inclined position.

The use of solar panels installed on the glass window as shading devices can be used as one of the passive cooling strategies in buildings. In addition to these benefits, the system can also be a source of renewable energy production that can be utilized for internal needs. Further research needed is the model and layout of solar panels as the most optimal and appropriate shading device.

\section{Acknowledgments}

This article is part of the research funded by the scheme of Sam Ratulangi University's excellent applied research (RTUU) for the year 2018-2019. We would like to thank the Head of Research Institute and Community Service and Rector of Sam Ratulangi University for their support.

\section{REFERENCES}

[1] J. I. Kindangen. Effect of the Placement of the Solar Panels on Corrugated Zinc Roofs to Lower the Indoor Air Temperatures, Technology Reports of Kansai University,
Vol. 62, No. 8, pp. 4361 - 4368, 2020.

[2] A. Freewan. Improving Thermal Performance of Offices in JUST Using Fixed Shading Devices, World Renewable Energy Congress, Linköping, Sweden, 2011, DOI: 10.3384/ecp110571860.

[3] B. Matusiak. A design method for fixed outside solar shading device, PLEA 2006 - The 23rd Conference on Passive and Low Energy Architecture, Geneva, Switzerland, 2006.

[4] Marie-Claude Dubois. A Method to Define Shading Devices Considering the Ideal Total Solar Energy Transmittance, Proceedings of the Third ISES Europe Solar Congress: Eurosun 2000, Copenhagen Denmark, 2000.

[5] C. P. Chou. The Performance of Daylighting with Shading Device in Architecture Design, Tamkang Journal of Science and Engineering, Vol. 7, No. 4, pp. 205 - 212, 2004.

[6] J. Carmody, K. Haglund. External Shading Devices in Commercial Buildings, Lund Institute of Technology, 2006.

[7] E. S. Lee, D. L. di Bartolomeo, F. M. Rubenstein, S. E. Selkowitz. Low-Cost Networking for Dynamic Window Systems, Energy and Buildings, Vol. 36, No. 6, pp. 503 - 513, 2004, DOI: $10.1016 /$ j.enbuild.2003.12.008.

[8] J. Yao, C. Yan. Evaluation of the Energy Performance of Shading Devices Based on Incremental Costs, World Academy of Science, Engineering and Technology, Vol. 5, No. 5, pp. 424 - 426, 2011.

[9] European Commission. Shading Systems, Solar Shading for the European Climates, Final Report, Energie Program, European Union's Fifth Framework Programme for Research, Technological Development and Demonstration, LBNL-52198, 2002.

[10] G. C. R. Gutierrez, L. C. Labaki. An Experimental Study of Shading Devices: Orientation Typology and Material, ASHRAE Transaction, pp. 1 - 7, 2007.

[11] J. T. Kim, G. Kim. Advanced External Shading Device to Maximize Visual and View Performance, SHB2009 - 2nd International Conference on Sustainable Healthy Buildings; Seoul, Korea. 2009.

[12] W. N. Hien, A. D. Istiadji. Effects of External Shading Devices on Daylighting and Natural Ventilation, 8th International IBPSA Conference, Eindhoven the Netherlands, 2003.

[13] V. Corrado, V. Serra, A. Vosila. Performance Analysis of External Shading Devices, PLEA 2004 - 21th Conference on Passive and Low Energy Architecture, Eindhoven the Netherlands, 2004.

[14] T. Rosencarntz. Performance of Energy Efficient Windows and Solar Shading Devices, Evaluation through Measurement and Simulations, Licentiate Thesis, Lund University, 2005

[15] J. Lu, D. Birru, K. Whitehouse. Using Simple Light Sensors to Achieve Smart Daylight Harvesting, BuildSys 2010, Proceedings of the 2nd ACM Workshop on Embedded Sensing Systems for Energy-Efficiency in Building, Zurich, Switzerland, pp. 73 - 78, 2010, DOI: 10.1145/1878431.187 8448 . 
[16] P. la Roche, M. Milne. Effects of Combining Smart Shading and Ventilation on Thermal Comfort, American Solar Energy Society (ASES), 2005, DOI: 10.1.1.530.2822.

[17] S. Selkowitz. New and Retrofit Fenestration Solutions for High-Performance Buildings, Workshop and Army Energy Summit, Chicago, 2009.

[18] S. Selkowitz, E. Lee. Integrating Automated Shading and Smart Glazings with Daylight Controls, International Symposium on Daylighting Buildings (IEA SHC Task 31), 2006

[19] S. Selkowitz, A. Anders. Windows of the Future: Materials Solutions to Global Energy Challenges, International Workshop on Glass for Harvesting, Storage \& Efficient Usage of Solar Energy The Impact on Energy Use, Peak Demand and Glare Control, Research Report, Center for Sustainable Building Research, University of Minnesota, Pittsburgh, 2008.
[20] V. M. Buhagiar, H. Calleja. Lighting and Thermal Performance of Innovative Shading Devices: New Insights into their Aesthetics and Control in a Mediterranean Climate, PLEA 2008 - 25th Conference on Passive and Low Energy Architecture, Dublin, 2008.

[21] A. Gaur, G. N. Tiwari. Performance of Photovoltaic Modules of Different Solar Cell, Journal of Solar Energy, Vol. 2013, pp.1 - 13, 2013, DOI: 10.1155/2013/734581.

[22] D. J. C. Mackay. Solar Energy in the Context of Energy Use, Energy Transportation and Energy Storage, Philosophical Transaction of the Royal Society, Vol. 372, No.1996, pp. 1 24, 2013, DOI: 10.1098/rsta.2011.0431.

[23] P. S. Pudyastuti, F. Kalista, G. D. Wibowo, H. S. Budinetro. Small Scale Integrated Sustainable Roof Design (Case Study in Surakarta City), Civil Engineering and Architecture, Vol. 8, No. 4, pp. 500 - 506, 2020, DOI: 10.13189/cea.2020.080 413. 